\title{
Lipid content of marine microalgae Chaetoceros muelleri Lemmermann (Bacillariophyceae) grown at different salinities
}

\author{
Mário Ubirajara Gonçalves Barros ${ }^{1 *}$ \\ Anderson Alan da Cruz Coelho ${ }^{2}$ \\ José William Alves da Silva ${ }^{1}$ \\ João Henrique Cavalcante Bezerra ${ }^{1}$ \\ Renato Teixeira Moreira ${ }^{1}$ \\ Wladimir Ronald Lobo Farias ${ }^{1}$ \\ Ricardo Lafaiete Moreira ${ }^{1}$ \\ ${ }^{1}$ Universidade Federal do Ceará, Campus Pici, CEP 60356-000, Fortaleza - CE, Brasil \\ ${ }^{2}$ Instituto Federal do Ceará, Campus Morada Nova, CEP 62940-000, Morada Nova - CE, Brasil \\ * Autor para correspondência \\ mariobarros86@hotmail.com
}

Submetido em 27/09/2013

Aceito para publicação em 20/03/2014

\section{Resumo}

Teor lipídico da microalga marinha Chaetoceros muelleri Lemmermann (Bacillariophyceae) cultivada em diferentes salinidades. A produção e armazenamento de lipídios por microalgas em resposta a variações nos fatores ambientais são específicos para cada espécie de microalga. O presente trabalho teve como objetivo avaliar o crescimento e a concentração de lipídios totais da microalga Chaetoceros muelleri cultivada em três diferentes salinidades $(15,25$ e 35). O experimento foi realizado em triplicatas, utilizando frascos de nove litros com volumes úteis de $7 \mathrm{~L}$, sendo cultivo do tipo estacionário ou "batch". A temperatura da sala de cultivo e a intensidade luminosa foram mantidas em $28 \pm 1^{\circ} \mathrm{C}$ e $20 \mu . \mathrm{mol} . \mathrm{m}^{-2} . \mathrm{s}^{-1}$, respectivamente. Os resultados mostraram que no presente trabalho, o rendimento lipídico $(10,41 \pm 1,89,10,87 \pm 2,10,12,33 \pm 1,81 \%$ nas salinidades 15 , 25 e 35, respectivamente) não foi influenciado pela concentração salina ( $>0,05)$. No entanto, a concentração celular máxima sofreu esta influência e foi significativamente maior $(\mathrm{p}<0,05)$ nas salinidades de 15 e 25 as quais obtiveram $16,3 \pm 1,50$ e $17,6 \pm 2,90 \times 10^{5}$ cel. $\mathrm{mL}^{-1}$, respectivamente.

Key words: Cultivo; Lipídeos; Microalgas

\section{Abstract}

The production and storage of lipids by microalgae in response to variations in environmental factors are specific for each microalgal species. The present study aimed to evaluate the growth and concentration of total lipids of the microalga C. muelleri Lemmermann cultivated at three different salinities $(15,25$ and 35). The experiment was conducted in triplicate, using 9-L containers (7-L working volume), with the culture being stationary or batch type. The temperature and light intensity of the cultivation room was kept at $28 \pm 1^{\circ} \mathrm{C}$ and 20 $\mu . \mathrm{mol} . \mathrm{m}^{-2} \cdot \mathrm{s}^{-1}$, respectively. The results showed that the lipid yield $(10.41 \pm 1.89,10.87 \pm 2.10$ and $12.33 \pm 1.81 \%$ 
at salinities of 15,25 and 35 , respectively) was not influenced by the salt concentration ( $>>0.05$ ), but the maximum cell concentration was significantly higher $(\mathrm{p}<0.05)$ at salinities of 15 and 25 , which was $16.3 \pm 1.50$ and $17.6 \pm 2.90 \times 10^{5}$ cells. $\mathrm{mL}^{-1}$, respectively.

Key words: Culture; Lipids; Microalgae

\section{Introduction}

Microalgae are considered potentially useful in applications in the food, cosmetic and pharmaceutical industries (OLAIZOLA, 2003; SOARES et al., 2006). At present, they are considered potential raw material for biodiesel production with physical and chemical characteristics similar to those currently used. The productivity of microalgae can surpass that of biofuel plant products worldwide, such as soybean and corn (CHISTI, 2007; MATA et al., 2010) and African palm oil (LORA; ANDRADE, 2009). These algae can be cultivated in industrial installations by using photobioreactors, avoiding any conflict with food production (CHISTI, 2007; JANAUN; ELLIS, 2010).

Marine species, especially diatoms, are even more promising due to the high lipid content (LOURENÇO, 2006). The species Chaetoceros muelleri Lemmermann has chorophyll $a, c 1$ and $c 2$, xanthophylls (fucoxanthin) and carotenes as the major pigments, which usually give it a yellowish-brown color. This species has a cell wall formed by two parts that fit within each other, mainly composed of silica, and uses chrysolaminarin and lipids as energy reserve substances (DE STEFANO et al., 2009).

Microalgae produce more oil under unfavorable culture conditions (HU et al., 2008). According to the cited authors, under optimal growth conditions, these organisms synthesize fatty acids, especially for esterification into membrane lipids, which constitute about $20-50 \%$ of their dry weight. But under unfavorable environmental or stress conditions, many microalgae change their lipid content through biosynthetic pathways for the formation and accumulation of neutral lipids, such as the triacylglycerols (TAG).

According to Alyabyev et al. (2007), salt stress causes a series of bioenergetic and biochemical changes in photosynthetic organisms. Among them, the most important are the increase in biopolymer and lipid catabolism, changes in the energy rate that supports biochemical processes, and changes in the permeability of the plasma membrane with disruption of ion homeostasis. These alterations are related to bioenergetic aspects and are essential for understanding the adaptive mechanisms of microalgae to salinity (ILLMAN et al., 2000; RAO et al., 2007).

Additional expenditure of metabolic energy under stress conditions is required to maintain ion balance and electrochemical gradients, to permit the biosynthesis of organic compounds that play a key role in the protection, osmoregulation, and maintenance of cell structure. Accordingly, the increase in energy release rate can ensure the rapid and effective acclimation of microalgae to stress (RODOLFI et al., 2008).

Microalgae are an attractive alternative to fossil fuels, due to their potential to achieve a high productivity using photosynthesis to convert solar energy into chemical energy, the short life cycle, high growth rate, high oil yield, and ability to absorb nutrients from waste waters (PATIL et al., 2008; HUANG et al., 2010).

This study aimed to evaluate the growth and total lipid content of the microalga $C$. muelleri cultivated at three different salinities $(15,25$ and 35).

\section{Material and Methods}

The microalga $C$. muelleri was obtained from the strain bank of the Laboratory of the Center for Technology in Aquaculture of the Department of Fishing Engineering from the Federal University of Ceará. Guillard f/2 culture medium was used for the maintenance of inocula and to carry out the experiments (GUILLARD, 1975).

The cultures were subjected to constant aeration (4 L air.min ${ }^{-1}$ ), by using a diaphragm pump (Hydor Bomba Ario 4). The temperature and light intensity in 
the cultivation room were kept at $28 \pm 1^{\circ} \mathrm{C}$ and $20 \mu$ mol.m ${ }^{2} \cdot \mathrm{s}^{-1}$, respectively. Irradiance was adjusted by regulating the distance between the light and the culture vessels, which was evaluated with the aid of a digital light meter (DIGITAL LUX TESTER YF-1065).

Constant illumination was provided by using two $40 \mathrm{~W}$ fluorescent lamps to obtain a higher photosynthetic rate, and hence higher productivity. All the material used in the experiment, including test tubes, Erlenmeyer flasks, and 9-L containers, were previously washed with water and detergent, rinsed and then autoclaved at $120^{\circ} \mathrm{C}$ for $15 \mathrm{~min}$. The cultures were performed at salinities 15, 25 and 35, in triplicate and continuous, using 9-L containers with a working volume of $7 \mathrm{~L}$; they consisted of 4.5 L of Guillard medium and 2.5 L of a pre-culture of C. muelleri produced in the same medium (inoculum). After microalgae inoculation, there was no addition of fresh medium throughout the growth of the culture, representing a stationary or batch type culture.

After the dilution of the inocula, the microalgal culture, at the three salinities and triplicates, were started with an optical density at $700 \mathrm{~nm}$ (diatoms) $\left(\mathrm{OD}_{700 \mathrm{~nm}}\right)$ of 0.100 , this value being used to represent the adaptation phase (lag). The cultures were maintained constant under the same conditions of light, nutrients, temperature, aeration and $\mathrm{pH}$ (8.0) (HANNA HI 221).

The monitoring of the cultures was carried out reading the optical density and cell counting. The $\mathrm{OD}_{700 \mathrm{~nm}}$ was determined with a spectrophotometer (HACH DR 2000). The initial optical density was determined using the equation 1.

$$
\mathrm{V}=\mathrm{v}-\left(\mathrm{D}_{\mathrm{F}} / \mathrm{D}_{\mathrm{I}}\right) \mathrm{x} \mathrm{v}
$$

where,

$\mathrm{V}$ - volume of the culture to be replaced by the culture medium,

v - volume of the culture, and

$D_{F}$ and $D_{I}$ - desired optical density and initial optical density of the inoculum, respectively.

Cell counting was done with the aid of a light microscope (TNE-10BN), using a mirrored Neubauer chamber. For counting, an aliquot of $5 \mathrm{~mL}$ was taken and fixed with formaldehyde neutralized with sodium tetraborate (borax); the results were expressed as cells. $\mathrm{mL}^{-1}$.

The mean cell counts, obtained from the three replicates for each salinity, were used to construct growth curves. Accordingly, the growth stages were identified throughout the cultures and used to determine the maximum cell concentrations $\left(\mathrm{X}_{\max }\right)$ and the growth rates in divisions per day $(\mathrm{K})$, which were obtained for the days with higher productivity (OHSE et al., 2008). The growth rate $(\mathrm{K})$ was calculated by using equation 2 :

$$
\mathrm{K}=\log _{2}\left(\mathrm{~N}_{\mathrm{f}}-\mathrm{N}_{\mathrm{o}}\right) / \mathrm{D}_{\mathrm{t}},
$$

where,

$\mathrm{K}$-is the growth rate,

$\mathrm{N}_{0}$ and $\mathrm{N}_{\mathrm{f}}$ - optical densities at the start and on the

day when the culture reached the maximum cell

concentration, respectively, and

$\mathrm{D}_{\mathrm{t}}-$ the duration of the culture, in days.

These two variables were subjected to linear correlation analysis and the linear regression equation was determined using equation 3 (XU et al., 2006).

$$
\mathrm{Y}=\mathrm{a} \cdot \mathrm{X}+\mathrm{b}
$$

where,

$\mathrm{Y}$ - corresponds to cell density (cells. $\left.\mathrm{mL}^{-1}\right)$,

$\mathrm{X}$ - optical density $\left(\mathrm{OD}_{700 \mathrm{~nm}}\right)$,

a - angular coefficient or slope, and

$b$ - linear coefficient.

At the end of the exponential growth phase, identified by spectrometry and cell count, the cultures were flocculated by adding $2 \mathrm{~N} \mathrm{NaOH}$. After the sedimentation of flakes, the culture medium was separated from the algal biomass by siphoning, and the biomass was then washed with distilled water to remove excess salt. Afterwards, the biomass of $C$. muelleri was oven-dried with circulating air at $60^{\circ} \mathrm{C}$ for $24 \mathrm{~h}$.

The lipids were extracted by placing $5 \mathrm{~g}$ of dry biomass of $C$. muelleri into an $250 \mathrm{~mL}$-Erlenmeyer flask with $25 \mathrm{~mL}$ of ethanol, $12.5 \mathrm{~mL}$ of chloroform and $5 \mathrm{~mL}$ of distilled water. The Erlenmeyer was sealed and immersed for $40 \mathrm{~min}$ in an ultrasonic bath 
(CRISTÓFOLI-1014-127 V) set at $40 \mathrm{kHz}$ and $80 \mathrm{~W}$. Next, $12.5 \mathrm{~mL}$ of chloroform and $12.5 \mathrm{~mL}$ of distilled water were added to the mixture, which was sonicated for another $20 \mathrm{~min}$. The solid fraction was obtained by vacuum filtration and oven-dried for $24 \mathrm{~h}$ at $105^{\circ} \mathrm{C}$ to recover the biomass. After the formation of two distinct phases in the filtered liquid, the nonpolar chloroform layer containing the lipids and the polar layer formed by methanol and water. The lipids were recovered and after evaporation of the chloroform, and the lipid content was quantified by weighing. The total lipid content in the biomass was determined by the weight difference of the solid mass before and after the extraction process. Three extractions of the biomass for each salinity were performed. The total percentage of lipid (PL) was calculated by equation 4 :

$\operatorname{PL}(\%)=($ weight before the extraction weight after the extraction) $\mathrm{x} 100) / 5 \mathrm{~g}$

To test for possible statistical differences between the lipid concentration, growth rate and maximum productivity of the cultures at the different salinities, the data were subjected to one-factor analysis of variance (ANOVA), and in case of significant differences, means of the treatments were compared by Tukey's test. In all analyses, the significance level adopted was 5\%.

\section{Results}

The daily determinations of OD ${ }_{700 \mathrm{~nm}}$ and cell counts (cells. $\mathrm{mL}^{-1}$ ) of the cultures at the three salinities showed strong and positive linear correlations (Figure 1 ). The growth curves (Figure 2) obtained from the cultures grown at salinities of 15 and 25 were fairly similar, with very sharp exponential growth phases, only differing on the last culture day, when cell density at a salinity of 25 was significantly higher. In the cultures performed at a salinity of 35 , the growth curve demonstrated a lower development of algal population throughout the culture.
FIGURE 1: Linear correlations between $\mathrm{OD}_{700 \mathrm{~nm}}$ and cell counts (cells. $\mathrm{mL}^{-1}$ ) of the cultures of Chaetoceros muelleri and respective linear regression equations, at salinities of 15 (A), 25 (B) and 35 (C). n=3. Each point on the curves refers to the mean of three replicates \pm standard deviation. The coefficient of determination (R2) and the regression lines are also indicated in each diagram.

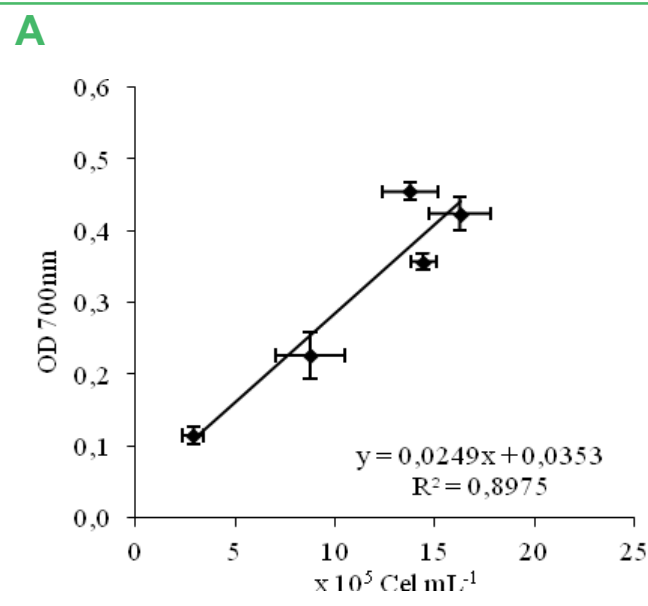

B

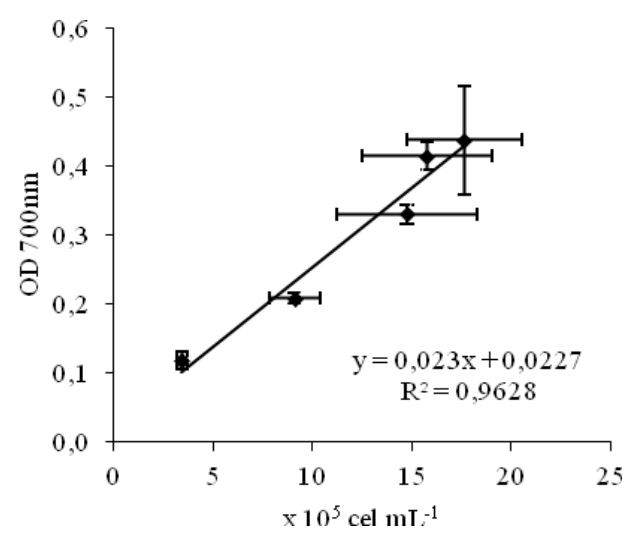

C

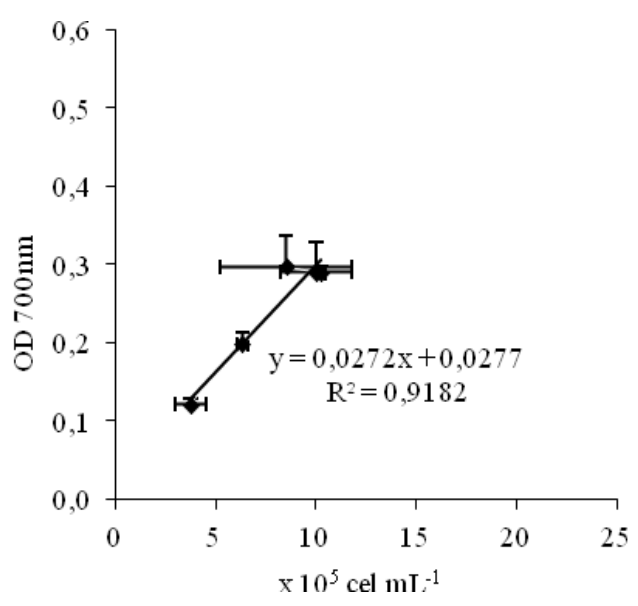


The exponential growth phase, or log phase, was observed from the first to the third day in the cultures carried out at the three salinities. Afterwards, the cultures at salinities of 15 and 25 entered a slow growth phase, which lasted until the fifth day only at a salinity of 25 . No induction phase of growth was observed for the three treatments. The culture grown at a salinity of 35 reached the stationary phase on the third day, and the cells tended to show senescence after the fourth day. On the other hand, after the reduction in relative growth on the fourth day, microalgal cultivation performed at the lowest salinity showed a trend toward senescence.

FIGURE 2: Growth curves of Chaetoceros muelleri grown at three salinities, 15, 25 and 35, for 5 days. Each point on the curves refers to the mean of three replicates \pm standard deviation.

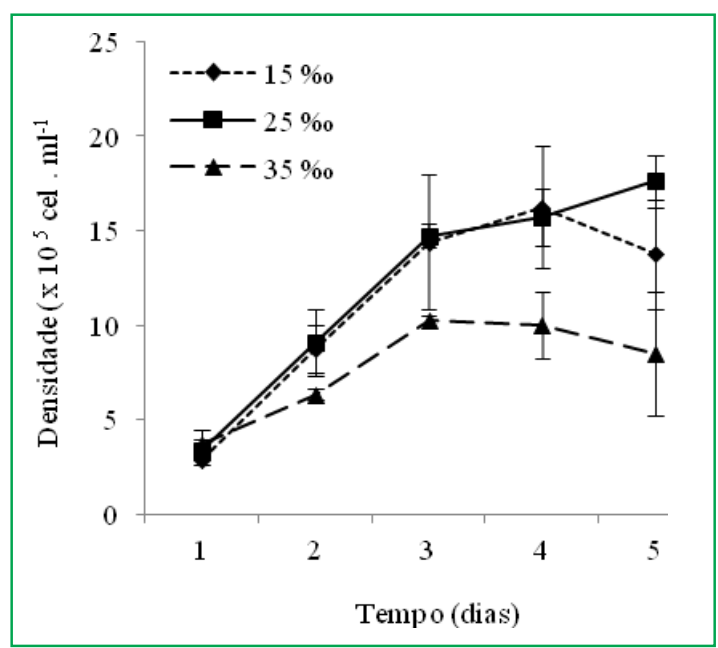

A significant variation $(\mathrm{p}<0.05)$ was observed in the maximum cell concentration (MCC) between the salinities studied. The cultures at salinities of 15 and 25 reached higher MCC values, without significant difference between them. The highest growth rate was observed at a salinity of 15 , reaching the maximum concentration around $73 \mathrm{~h}$ (Table 1).
In the present study, the lipid yield was not influenced by salinity, while the maximum cell concentration was significantly higher $(\mathrm{p}<0.05)$ at salinities of 25 and 15 (Table 1). Thus, a greater production of total lipids could be achieved, especially in large scale, considering the total cells produced at these salinities.

The lipid yield values at the three salinities were not statistically different $(p<0.05)$ in relation to the dry weight of the microalgae, where content values of $10.41 \pm 1.89,10.87 \pm 2.10$ and $12.33 \pm 1.81 \%$ were obtained for salinities of 15,25 and 35 , respectively.

\section{Discussion}

Microalgal lipid content seems to be highly variable and is related to environmental conditions. The influence of light intensity, temperature, nutrients and the stage of culture growth on the content of lipids and fatty acids in microalgae have been extensively studied. The production and storage of lipids by microalgae in response to variations in environmental factors are specific for each species, hindering generalization. Nevertheless, according to the literature, it appears that the lipid content of diatoms increases dramatically when the cultures reach the stationary phase due to growthlimiting factors, such as the reduction in the levels of silicate and nitrogen (PERNET et al., 2003).

Oshe et al. (2008) cultivated the same species at a salinity of 30 and observed a decrease in growth rate, requiring around seven days to reach the stationary phase. Khatoon et al. (2010), in analyzing the effect of salinity on three diatom species (Navicula, Cymbella and Amphora) grown in Conway medium at $28^{\circ} \mathrm{C}$ and light intensity of $31.9 \mu \mathrm{mol}$.photons $\mathrm{m}^{-2} \cdot \mathrm{s}^{-1}, 12: 12 \mathrm{~h}$ light-dark cycle, obtained a biomass increase from

TABLE 1: Kinetic yield parameters of Chaetoceros muelleri cultures at three different salinities.

\begin{tabular}{|c|c|c|c|c|}
\hline Salinity & $\begin{array}{c}\text { TMC }^{1} \\
\text { (hours) }\end{array}$ & $\begin{array}{c}\text { GR }^{2} \\
\text { (divisions day }^{-1} \text { ) }\end{array}$ & $\begin{array}{c}\text { MCC }^{3} \\
\left(\times 10^{5} \text { cells.mL } L^{-1}\right)\end{array}$ & $\begin{array}{l}\mathbf{L Y} Y^{4} \\
(\%)\end{array}$ \\
\hline 15 & $73 \pm 1^{\mathrm{b} 5}$ & $0.90 \pm 0.12^{\mathrm{a}}$ & $16.3 \pm 1.50^{\mathrm{a}}$ & $10.41 \pm 1.89^{\mathrm{a}}$ \\
\hline 25 & $96 \pm 1^{\mathrm{a}}$ & $0.55 \pm 0.11^{\mathrm{b}}$ & $17.6 \pm 2.90^{\mathrm{a}}$ & $10.87 \pm 2.10^{\mathrm{a}}$ \\
\hline 35 & $48 \pm 1^{\mathrm{c}}$ & $0.63 \pm 0.18^{\mathrm{ab}}$ & $10.3 \pm 0.30^{\mathrm{b}}$ & $12.33 \pm 1.81^{\mathrm{a}}$ \\
\hline
\end{tabular}

${ }^{1}$ Time of maximum concentration; ${ }^{2}$ Growth rate; ${ }^{3}$ Maximum cell concentration; ${ }^{4}$ Lipid yield; ${ }^{5}$ Different letters represent significant difference $(\mathrm{p}<0.05)$. 
the eighth day of culture, reaching a maximum on the twelfth day at all salinities tested (15, 20, 25, 30 and 35). The same authors found that biomass increased with salinity, in accordance with Ghezelbash et al. (2008), who showed that microalgae cultivated at a salinity of 40 g.L. $\mathrm{L}^{-1}$ had the highest biomass. This result was similar to the findings of the present study. The same authors described that among several environmental factors, salinity also limits the growth and productivity of microorganisms.

The microalgae cultivated at the three salinities were flocculated to obtain dry biomass on the fifth day, by which time there was a trend toward stagnation in population growth, probably resulting from decreased availability of nutrients in the medium, among other factors. For an optimal performance in microalgal culture, several nutrients are essential for algal growth, such as nitrogen, hydrogen, phosphorus, calcium, magnesium, potassium and sulfur, as well as micronutrients such as iron, boron, copper, zinc, vanadium, molybdenum and sodium, usually present in culture media (SIPAÚBATAVARES; ROCHA, 2003).

Renaud et al. (2002) examined the growth of 18 microalgal species at a salinity of $25 \pm 1$, temperature of $25 \pm 1^{\circ} \mathrm{C}$. The authors found a density of $28.9 \times 10^{5}$ cells. $\mathrm{mL}^{-1}$ at salinities of 15 and 25 and obtained growth rates of 0.87 and 0.56 divisions.day ${ }^{-1}$, respectively. The culture of the diatom C. muelleri in Guillard $\mathrm{f} / 2$ medium at $19^{\circ} \mathrm{C}$, with injection of $\mathrm{CO}_{2}$, resulted in a MCC of 30 to $120 \mathrm{x}$ $10^{5}$ cells.mL $\mathrm{mL}^{-1}$. Krichnavaruck et al. (2005) cultured $C$. calcitrans in a photobioreactor and obtained a maximum cell density of $88 \times 10^{5}$ cells. $\mathrm{mL}^{-1}$ in stationary phase, showing the efficiency of these structures.

The culture of the diatoms $C$. wighami and Amphora coffeaeformis in Guillard $\mathrm{f} / 2$ culture medium, at a salinity of 30 , temperature of $28^{\circ} \mathrm{C}$, and irradiance of $40 \mu \mathrm{mol} . \mathrm{m}^{-2} . \mathrm{s}^{-1}$ resulted in growth rates of 0.95 and 0.72 divisions.day ${ }^{-1}$ (RAJADURAI et al., 2005). For the diatom Thalassiosira weissflogii, Reinfelder et al. (2000) observed growth rates ranging from 1 to 1.5 divisions. day $^{-1}$, which were not significantly different from the growth rate obtained for $C$. muelleri at a salinity of 15 in our study.
Pacheco-Vega and Sánchez-Saavedra (2009) obtained a lipid content of $19.70 \pm 1.99$ and $22.80 \pm 3.74 \%$ for $C$. muelleri in the Guillard $\mathrm{f} / 2$ medium and in a new medium, respectively. This new culture medium was prepared with $72 \%$ phosphate, phosphoric acid as phosphorus source and a liquid fertilizer, with $32 \%$ of total nitrogen supplied as urea (16.4\%) and ammonium nitrate $(15.6 \%)$, added to provide concentrations of $\mathrm{P}$ and $\mathrm{N}$ equal to those in Guillard medium. These cultures were maintained at $21^{\circ} \mathrm{C}$ with constant light $(100 \mu \mathrm{mol}$ photons $\left.\cdot \mathrm{m}^{-2} \cdot \mathrm{s}^{-1}\right)$. Both media were prepared with sea water filtered (1- $\mu \mathrm{m}$ mesh size) and enriched with 0.107 mol. $\mathrm{L}^{-1} \mathrm{Si}$. In another study with the same microalga cultivated in Guillard medium, with a photoperiod of 18:6, lipid yields of 25.25 and $11.67 \%$ were obtained for salinities of 25 and 35, respectively (ARAUJO et al., 2011). Wahlen et al. (2011) attained a lipid content of $44 \pm 0.87 \mathrm{mg} .100 \mathrm{mg}^{-1}$ biomass for the diatom C. gracilis.

Renaud et al. (2002) investigated the influence of temperature on growth and chemical composition of fatty acids of Chaetoceros sp. at temperatures around $25^{\circ} \mathrm{C}$ and found about $16.8 \%$ lipids for this species. The fatty acids of microalgae can be influenced by several factors, including temperature (MORAIS; COSTA, 2008). The cell membrane fluidity depends on the degree of unsaturation of fatty acids, with the membrane being more fluid with increasing unsaturation (MARSZALEK; LODISH, 2005). Yeesang and Cheirsilp (2010) observed the effect of light when culturing Botryococcus spp. using different light intensities. The lipid content was greater when the culture was exposed to light of 33 to $49.5 \mu \mathrm{mol}$ photons. $\mathrm{m}^{-2} . \mathrm{s}^{-1}$.

Takagi et al. (2006) cultured the microalga Dunaliella tertiolecta and found that cell concentration decreased with increase in $\mathrm{NaCl}$ concentration in the culture medium, but an increase in intracellular lipid content and a high percentage of triglycerides were seen in the exponential growth phase. However, increasing the $\mathrm{NaCl}$ concentration was not a good strategy, due to the sharp decrease in cell concentration for this species.

Converti et al. (2009) asserted that the growth and lipid content of Chlorella vulgaris can be affected by the temperature of the culture. The authors found a $17 \%$ reduction in growth rate at $30^{\circ} \mathrm{C}$, when 
compared to a temperature of $25^{\circ} \mathrm{C}$, and a significant reduction in the amount of lipids (from $14.71 \pm 0.30$ to $5.90 \pm 0.42 \mathrm{~g} .100 \mathrm{~g}$ dry weight $\left.{ }^{-1}\right)$. For the microalga Nannochloropsis oculata, the lipid content doubled from $7.90 \pm 0.21$ to $14.92 \pm 0.82 \mathrm{~g} .100 \mathrm{~g}$ dry weight ${ }^{-1}$ under the same conditions of temperature. When the nitrogen concentration in the medium was reduced by $75 \%$, there was an increase in lipid content from 7.90 to $15.31 \%$ in $N$. oculata, and from 5.90 to $16.41 \%$ in C. vulgaris. In microalgal cultures, each species has an ideal temperature, which is usually between 20 and $30^{\circ} \mathrm{C}$ (CHISTI, 2007).

The use of photobioreactors is also an alternative for a greater and faster productivity, as well as the use different techniques to recover the microalgae from the culture medium and the use of the biomass after lipid extraction to obtain other compounds with biological activity. Besides, the modulation of other parameters such as temperature, photoperiod, irradiance, composition of the culture medium, and type of culture can be done for possible increase in lipid yield.

In conclusion, the variation of salinity in the culture medium had no influence on the lipid production of the microalga C. muelleri. However, this variation resulted in a significant increase in productivity and greater cell concentration at salinities of 15 and 25 , demonstrating the greater advantage of growing this microalga under these salinity conditions.

In addition, these results indicate that a higher yield of total lipids can be obtained in C. muelleri, especially on a large scale, considering the total number of cells produced at these salinities. Further and more detailed studies are needed, such as the characterization and qualification of lipids found in the species.

\section{References}

ALYABYEV, A. J.; LOSEVA, N. L.; GORDON, L. K. H.; ANDREYEVA, I. N.; RACHIMOVA, G. G.; TRIBUNSKIH, V. I.; PONOMAREVA, A. A.; KEMP, R. B. The effect of changes in salinity on the energy yielding processes of Chlorella vulgaris and Dunaliella maritima cells. Thermochimica Acta, Salamanca, v. 458, n. 1-2, p. 65-70, 2007.

ARAUJO, G. S.; MATOS, L. J. B. L.; GONÇALVES, L. R. B.; FERNANDES, A. N.; FARIAS, W. R. L. Bioprospecting for oil producing microalgal strains: Evaluation of oil and biomass production for ten microalgal strains. Bioresource Technology, Oxford, v. 102, n. 8, p. 5248-5250, 2011.

CHISTI, Y. Research review paper: biodiesel from microalgae. Biotechnology Advances, Palmerston North, v. 25, n. 3, p. 294306, 2007.

CONVERTI, A.; CASAZZA, A. A.; ORTIZ, E, Y.; PEREGO, P.; BORGHI, M. D. Effect of temperature and nitrogen concentration on the growth and lipid content of Nannochloropsis oculata and Chlorella vulgaris for biodiesel production. Chemical Engineering and Processing: Process Intensification, Philadelphia, v. 48, n. 6, p. 1146-1151, 2009.

DE STEFANO, M.; DE STEFANO, L.; CONGESTRI, R. Functional morphology of micro- and nanostructures in two distinct diatom frustules. Superlattices and Microstructures, Amsterdam, v. 46, n. 1-2, p. 64-68, 2009.

GHEZELBASH, F.; FARBOODNIA, T.; HEIDARI, R.; AGH, N. Effects of different salinities and luminance on growth rate of the green microalgae Tetrasemis chuii. Research Journal of Biological Sciences, Taipé, v. 3, n. 3, p. 311-314, 2008.

GUILLARD, R. R. L. Culture of phytoplankton for feeding marine invertebrates. In: SMITH, W. L.; CHANLEY, M. H. (Ed.). Culture of marine invertebrate animal. New York: Plenum Publishing, 1975. p. 29-60.

HU, Q.; SOMMERFELD, M.; JARVIS, E.; GHIRARDI, M.; POSEWITZ, M.; SEIBERT, M.; DARZINS, A. Microalgal triacylglycerols as feedstocks for biofuel production: perspectives and advances. The Plant Journal, Barcelona, v. 54, n. 4, p. 621$639,2008$.

HUANG, G.; CHEN, F.; WEI, D.; ZHANG, X.; CHEN, G. Biodiesel production by microalgal. Applied Energy, Bedford, v. 87 , n. 1 , p. $38-46,2010$.

ILLMAN, A. M.; SCRAGG, A. H.; SHALES, S. W. Increase in Chlorella strains calorific values when grown in low nitrogen medium. Enzyme and Microbial Technology, Amsterdam, v. 27, n. 8, p. 631-635, 2000.

JANAUN, J.; ELLIS, N. Perspectives on biodiesel as a sustainable fuel. Renewable and Sustainable Energy Reviews, Pulau Pinang, v. 14, n. 4, p. 1312-1320, 2010.

KHATOON, H.; BANERJEE, S.; MDYUSO F.; SHARI, M. Effects of salinity on the growth and proximate composition of selected tropical marine periphytic diatoms and cyanobacteria. Aquaculture Research, Oxford, v. 41, n. 9, p. 1348-1355, 2010.

KRICHNAVARUK, S.; LOATAWEESUP, W.; POWTONGSOOK, S.; PAVASANT, P. Optimal growth conditions and the cultivation of Chaetoceros calcitrans in airliftphotobioreactor. Chemical Engineering Journal, New York, v. 105, n. 3, p. 91-98, 2005.

LORA, E. S.; ANDRADE, R. V. Biomass as energy source in Brazil. Renewable and Sustainable Energy Reviews, Pulau Pinang, v. 13, n. 4, p. 777-788, 2009.

LOURENÇO, S. O. Cultivo de microalgas marinhas: princípios e aplicações. Vol. 1. São Carlos: Rima, 2006. p. 588-620.

MARSZALEK, J. R.; LODISH, H. F. Docosahexaenoic acid, fatty acid-interacting proteins, and neuronal function: breastmilk and fish are good for you. Annual Review of Cell and Developmental Biology, Palo Alto, v. 21, p. 633-657, 2005. 
MATA, T. M.; MARTINS, A. A.; CAETANO, N. S. Microalgae for biodiesel production and other applications: a review. Renewable and Sustainable Energy Reviews, Pulau Pinang, v. 14, n. 1, p. 217-232, 2010.

MORAIS, M., G.; COSTA, J. A. V. Perfil de ácidos graxos de microalgas cultivadas com dióxido de carbono. Ciência e Agrotecnologia, Lavras, v. 32, n. 4, p. 1245-1251, 2008.

OHSE, S.; DERNER, R. B.; OZÓRIO, R. A.; BRAGA, M. V. C.; CUNHA, P.; LAMARCA, C. P.; SANTOS, M. E. Crescimento de microalgas em sistema autotrófico estacionário. Revista Biotemas, Florianópolis, v. 21, n. 2, p. 7-18, 2008.

OLAIZOLA, M. Commercial development of microalgal biothecnology: from the test tube to the marketplace. Biomolecular Engineering, Santa Cruz, v. 20, n. 4-6, p. 359-466, 2003.

PACHECO-VEGA, J. M.; SÁNCHEZ-SAAVEDRA, M. D. P. The biochemical composition of Chaetoceros muelleri (Lemmermann Grown) with an agricultural fertilizer. Journal of the World Aquaculture Society, Baton Rouge, v. 40, n. 4, p. 556-560, 2009.

PATIL, V.; TRAN, K. Q.; GISELROD, H. R. Towards sustainable production of biofuels from microalgae. International Journal of Molecular Sciences, Basel, v. 9, n. 7, p. 1188-1195, 2008.

PERNET, F.; TREMBLAY, R.; ROUSSY, M.; DEMERS, E. Variation of lipid class and fatty acid composition of Chaetoceros muelleri and Isochrysis sp. grown in a semicontinuous system. Aquaculture, Amsterdam, v. 221, n. 1-4, p. 393-406, 2003.

RAJADURAI, M.; POORNIMA, E. H.; NARASIMHAN, S. V.; RAO, V. N. R.; VENUGOPALAN, V. P. Phytoplankton growth under temperature stress: laboratory studies using two diatoms from a tropical coastal power station site. Journal of Thermal Biology, Durham, v. 30, n. 4, p. 299-305, 2005.

RAO, A. R.; DAYANANDA, C.; SARADA, R.; SHAMALA, T. R.; RAVISHANKAR, G. A. Effect of salinity on growth of green alga Botryococcus braunii and its constituents. Bioresource Technology, Oxford, v. 98, n. 3, p. 560-564, 2007.

RENAUD, S. M.; THINH, L. V.; LAMBRINIDIS, G.; PARRY, D. L. Effect of temperature on growth, chemical composition and fatty acid composition of tropical Australian microalgae grown in batch cultures. Aquaculture, Amsterdam, v. 211, n. 1-4, p. 195214, 2002.
REINFELDER, J. R.; KRAEPIEL, A. M. L.; MOREL, F. M. M.. Unicellular C4 photosynthesis in a marine diatom. Nature, London, v. 407, n. 1, p. 996-999, 2000.

RODOLFI, L.; ZITTELLI, G. C.; BASSI, N.; PADOVANI, G.; BIONDI, N.; BONINI, G. Microalgae for oil: strain selection, induction of lipid synthesis and outdoor mass cultivation in a lowcost photobioreactor. Biotechnology and Bioengineering, Malden, v. 102, n. 1, p. 100-112, 2008

SIPAÚBA-TAVARES, L. H.; ROCHA, O. Produção de plâncton (fitoplâncton e zooplâncton) para alimentação de organismos aquáticos. São Carlos: RiMa, 2003. 106 p.

SOARES, R.; PEIXOTO, S.; WASIELESKY, W.; D'INCAO, F. Effect of different food items on effect of different food items on the survival and growth of Farfantepenaeus paulensis post larvae. Aquaculture Research, Oxford, v. 37, n. 14, p. 1413-1418, 2006.

TAKAGI, M.; KARSENO; YOSHIDA, T. Effect of salt concentration on intracellular accumulation of lipids and triacylglyceride in marine microalgae Dunaliella cells. Journal of Bioscience and Bioengineering, Osaka, v. 101, n. 3, p. 223-226, 2006.

WAHLEN, B. D.; WILLIS, R. M.; SEEFELDT, L. C. Biodiesel production by simultaneous extraction and conversion of total lipids from microalgae, cyanobacteria, and wild mixed-cultures. Bioresource Technology, Oxford, v. 102, n. 3, p. 2724-2730, 2011.

XU, H.; MIAO, X. L.; WU, Q. Y. High quality biodiesel production from a microalga Chlorella protothecoides by heterotrophic growth in fermenters. Journal of Biotechnology, Bielefeld, v. 126, n. 4, p. 499-507, 2006.

YEESANG, C.; CHEIRSILP, B. Effect of nitrogen, salt, and iron content in the growth medium and light intensity on lipid production by microalgae isolated from freshwater sources in Thailand. Bioresource Technology, Oxford, v. 102, n. 3, p. 3034-3040, 2010. 